\begin{tabular}{|l|l|}
\hline 2. To: (Receiving Organization) & 3. From: (Originating Organization) \\
R. W. Root & Numatec Hanford Corporation \\
\hline 5. Proj./Prog./Dept./Div.: & 6. Design Authority/ Design Agent/Cog. \\
Waste Management & Engr.: \\
\hline
\end{tabular}

8. Originator Remarks:

For Approval and Release

11. Receiver Remarks:

11A. Design Baseline Document? [] Yes [X] No
4. Related EOT No.:

N/A

7. Purchase Order No.:

N/A

9. Equip./Component No.:

N/A

10. System/Bldg./Facility:

N/A

12. Major Assm. Dwg. No.:

N/A

13. Permit/Permit Application No.:

N/A

14. Required Response Date: $10 / 10 / 98$

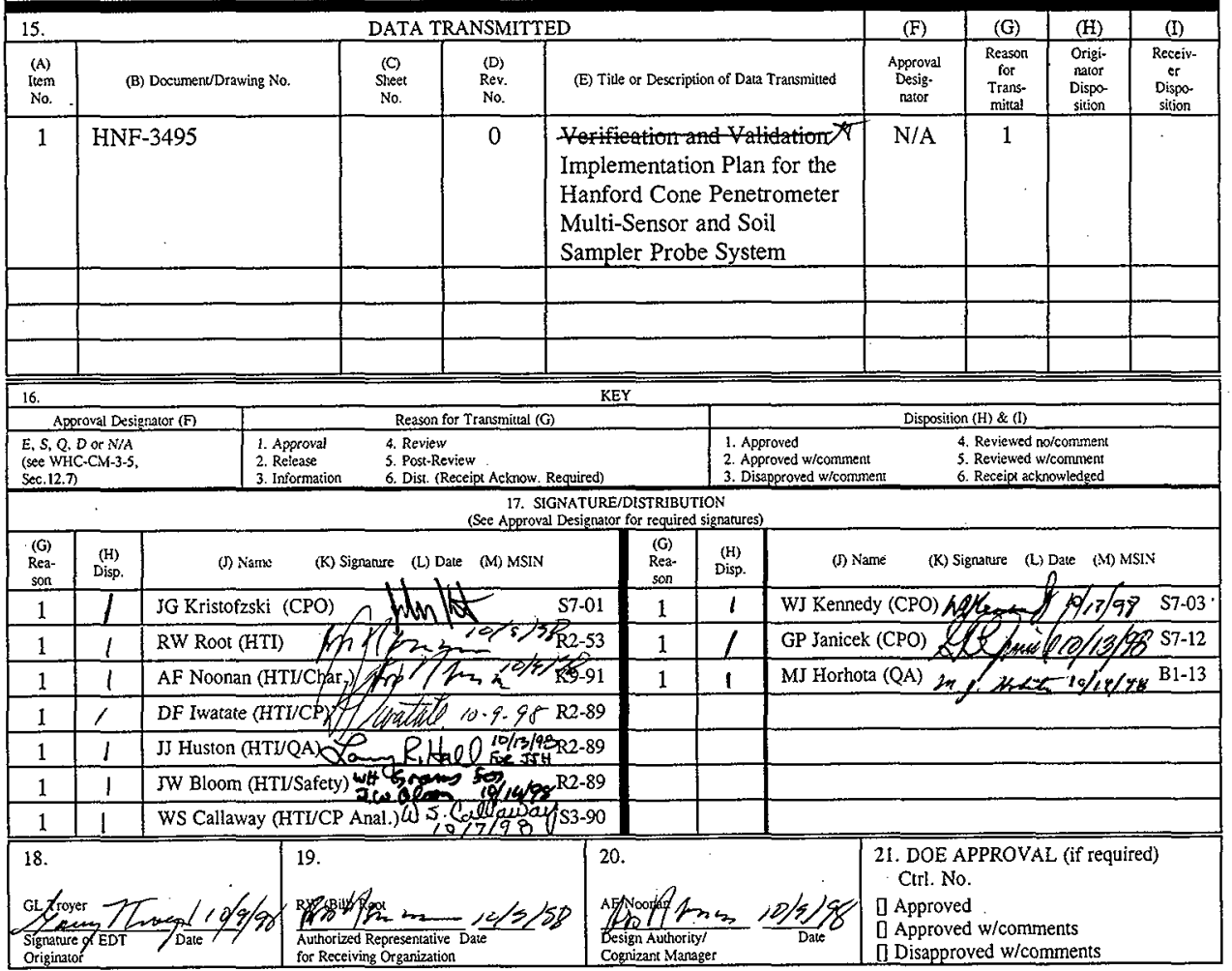

BD-7400-172-2 (05/96) GEF097 


\title{
Implementation Plan for the Hanford Cone Penetrometer Multi-Sensor and Soil Sampler Probe System
}

\author{
G.L. Troyer
}

Numatec Hanford Corporation, Richland, WA 99352

U.S. Department of Energy Contract DE-AC06-96RL13200

$\begin{array}{ll}\text { EDT } / E C N: 617395 & \text { UC: } 2030 \\ \text { Org Code: } 88200 & \text { Charge Code: } 103262 / \text { E100 } \\ \text { B\&R Code: EW3130010 } & \text { TotaT Pages: } 8\end{array}$

Key Words: cone, penetrometer, verification, validation, soil, sampler, software

Abstract: This document describes the requirements for verification and validation (V\&V) of the integrated sensor and data reduction processes for the data acquisition system developed for the Hanford cone penetrometer $\mathrm{p}$ latform.

TRADEMARK DISCLAIMER. Reference herein to any specific commercial product, process, or service by trade name, trademark, manufacturer, or otherwise, does not necessarily constitute or imply its endorsement, recommendation, or favoring by the United states Government or any agency thereof or its contractors or subcontractors.

Printed in the United States of America. To obtain copies of this document, contact: Document Control Services, P.0. Box 950, Mailstop H6-08, Richland WA 99352, Phone (509) 372-2420;

Fax (509) 376-4989.

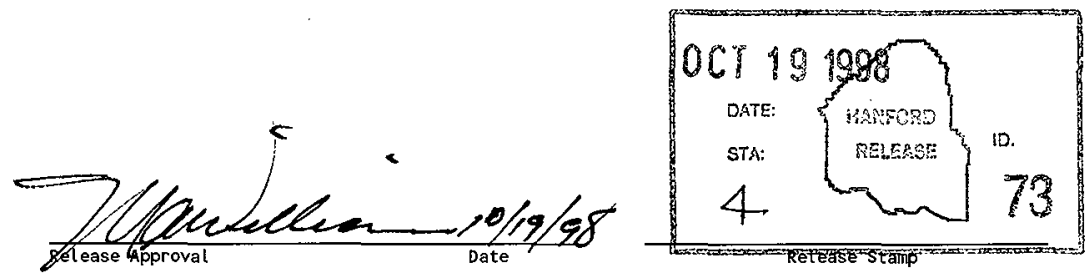

Approved for Public Release 
HNF-3495 Rev. 0

Implementation Plan for the Hanford Cone Penetrometer

Multi-Sensor and Soil Sampler Probe System

\author{
Prepared by \\ Numatec Hanford Corporation \\ October 1998
}

For the

United States Department of Energy

Richland Operations Office

Richland WA 
Implementation Plan for the Hanford Cone Penetrometer

Multi-Sensor and Soil Sampler Probe System

\section{Table of Contents}

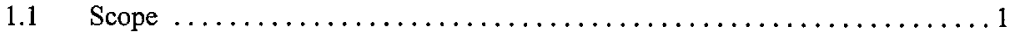

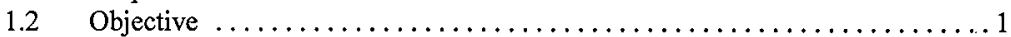

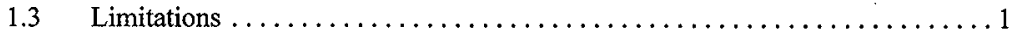

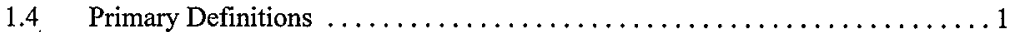

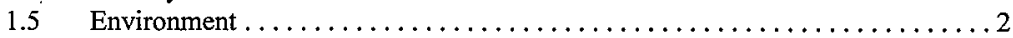

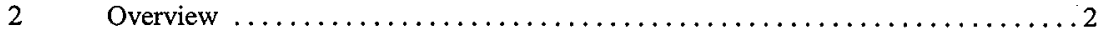

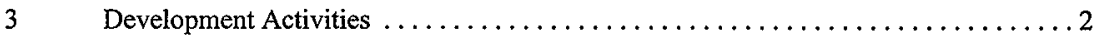

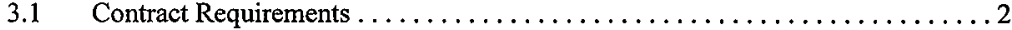

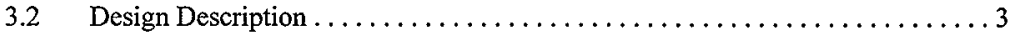

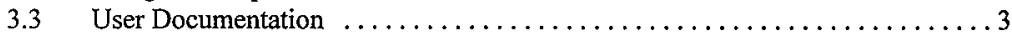

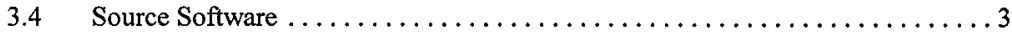

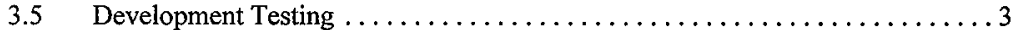

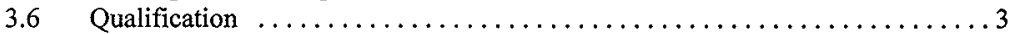

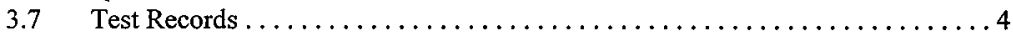

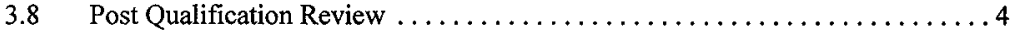

$4 \quad$ Responsibilities $\ldots \ldots \ldots \ldots \ldots \ldots \ldots \ldots \ldots \ldots \ldots \ldots \ldots \ldots \ldots \ldots$

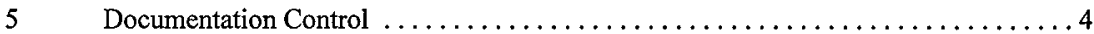

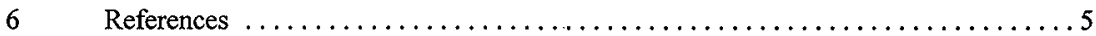

Tables

Table 1 Phase Responsibilities.$\ldots \ldots \ldots \ldots \ldots \ldots \ldots \ldots \ldots \ldots \ldots \ldots \ldots \ldots$ 
Implementation Plan for the Hanford Cone Penetrometer

Multi-Sensor and Soil Sampler Probe System

\section{Introduction}

This document defines the implementation plan associated with the development of the Hanford Tank Initiative (HTI) vadose zone cone penetrometer (CP) multi-sensor and soil sampler probes demonstration deployment.

\subsection{Scope}

This document describes the requirements for verification and validation (V\&V) of the integrated sensor and data reduction processes for the data acquisition system developed for the Hanford cone penetrometer platform.

\subsection{Objective}

The objective of this document is to identify actions which assure that the equipment and associated software meets the needs of the HTI CP demonstration project. In addition, this document establishes the delineation of activities to assure that the system is independently validated for use by Project Hanford Management Contract (PHMC) activities.

\subsection{Limitations}

This document is limited to discussions regarding initiation, design, system characterization, and delivery validation. The system comprises hardware sensors, electronic data conversions, and embedded control programs which are controlled by common hardware qualification testing ${ }^{1}$ approaches.

\subsection{Primary Definitions}

For this document, the following primary definitions are used:

Verification: A testing process which establishes performance in relation to a requirement or specification.

Validation: An evaluation process which assures that the system can operate in the intended environment and meets the original intent. 
HNF-3495 Rev. 0

Development Testing:

A testing process which determines the actual performance parameters of the system and provides a baseline for quality control.

Qualification: A final testing process which confirms performance established by development testing related to intent of specification.

\subsection{Environment}

The CP system will contain a mix of contractor developed and off the shelf (OTS) software integrated into a data acquisition system (DAS). The SELLER supplied embedded software provides control and data reduction support to the various physical sensor systems in the probe and DAS. Since the software development is controlled by contract with a SELLER ${ }^{2}$, the testing process is limited to the various system documents and activities of specification, design description, user documentation, operating software, and test records per intent of various procedures ${ }^{1}$. The supplied system contains binaries executable by a run time system; no classical source code is available. This limit is further supported by the nature of the demonstration project and the goals identified in the Statement of Work ${ }^{2}$ (SOW). Testing is performed by confirmation of hardware sensor measurement results compared to known standards. The test records include test procedures, case records, and test reports.

\section{Overview}

The HTI is chartered to leverage new technologies for the characterization and ultimate clean-up of Hanford nuclear defense tankage and materials. Certain Hanford waste tanks are known to have leaked radioactive material into surrounding soils. Clean-up approaches and needs statements are dependent on information regarding the extent of leakage plumes in the tank farm backfill soil and vadose zone. Subsurface characterization through traditional driven wells is expensive and sensor type deployment is limited. Cone penetrometer technology was selected as a deployment platform to allow rapid soil penetration and multiple on-board chemical and physical sensors. Innovative additions which result in a multi-sensor probe (MSP) are prescribed. The MSP and an associated soil sampling system will obtain several types of data for each penetration.

\section{Development Activities}

The various activities identified in section 1.5 are described in the following. A summary of responsibilities for each activity is found in Table 1 .

\subsection{Contract Requirements}


As noted, the CP demonstration requires the integration of contract and OTS software into the DAS. The performance requirements have been provided as a part of an SOW to the SELLER. The SOW and requirements were developed by the CP team, reviewed and approved by PHMC management, technical representatives, quality assurance and the SELLER. This provides the basis for the remainder of the deployment and demonstration effort and becomes the primary contract document.

\subsection{Design Description}

Based on the requirements, a design description is provided by the vendor. This document is verified for compliance to the SOW instructions/requirements by the users technical team. It provides information on the relationship of the various components to each other and shows how data and control flows through the system.

\subsection{User Documentation}

User documentation describes how the system is operated. It comprises procedures, operation basis, and maintenance documentation. It is developed by the vendor and reviewed and approved by the user technical team. It is provided as part of the deliverables for final testing phases.

\subsection{Source Software Code}

Software structure listings for contractor-developed portions of the system software will be provided by the vendor as a part of the final system deliverables. Listings shall be indexed, correlated with system functions, and show control between listings and executable code. The listings package and binaries will become a part of the controlled documentation for the project. Completeness shall be verified by the user technical team. This section of documentation is comparable to As Built drawings of physical components.

\subsection{Development Testing}

Prior to and during delivery, the system will undergo development testing. This activity will establish the baseline limits of the system such as sensor responses, algorithm performance, and process sequences. This testing is performed by the SELLER and witnessed and approved by the BUYER technical team. The criteria are defined by the requirements and a development test plan. The development test plan is provided by the SELLER. A report containing the test cases and results will be provided for system project control documentation. The results will be verified by the BUYER technical team.

\subsection{Qualification Testing}

During the system delivery process, a qualification test will be performed which confirms the 
HNF-3495 Rev. 0

basic performance of the system as defined by the SOW ${ }^{2}$. The purpose of this testing is to confirm that the delivered system has not significantly changed from development, meets the intent of the requirements, and shows that the system is ready to demonstrate. This testing is performed by the BUYER technical team as an independent test from the SELLER characterization. SELLER representatives will support as required. The results will become a part of the project control documentation. The results will be verified by BUYER quality assurance.

\subsection{Test Records}

Each of the identified activities (3.1 through 3.6) will generate a record of status regarding the completeness of the activity. Where testing occurs, the results of the tests will be validated by the BUYER technical team. A test report will be generated which attests to the completeness of the deliverables, degree of compliance to intended need, and acceptability for contract obligations. These reports will become a part of the project controlled documentation.

\subsection{Post Qualification Review}

Subsequent to the qualification testing, a review will be performed to provide a closeout to the development process. This review will assess completeness of records and provide formal validation of the system against the SOW. This review will assess the impact of any exceptions found during various test phases.

\section{Responsibilities}

The responsibilities of various project participants are identified in Table 1.

\section{Documentation Control}

The documentation for the $\mathrm{CP} / \mathrm{MSP}$ effort is maintained as a Commercial Vendor Information (CVI) file. The file is designated as the "HTI Project File" and has an engineering tracking number ETN-97-0014. At least one copy of all generated documents describing the development, testing, reviews, and system descriptive information is maintained therein. Certain documents are subject to change as the demonstration progresses. These are governed by Engineering Change Notice per PHMC guidelines. 
HNF-3495 Rev. 0

\begin{tabular}{||l|l|l|l||}
\hline \multicolumn{4}{|c|}{ Table 1 Phase Responsibilities } \\
\hline \hline Activity & \multicolumn{1}{|c|}{ Vendor } & \multicolumn{1}{c|}{ User } & \multicolumn{1}{c||}{ User QA } \\
\hline \hline Contract Requirements & Approve & Create & Approve \\
\hline Design Description & Create & Approve & Review \\
\hline User Documentation & Create & Review/Approve & \\
\hline Software Source Code & Create & Review/Approve & Review \\
\hline Development Testing & Create/Perform & $\begin{array}{l}\text { Review/Witness/ } \\
\text { Approve }\end{array}$ & Review \\
\hline Qualification Testing & Support & Create/Control & Review/Approve \\
\hline Test Reports & $\mathrm{n} / \mathrm{a}$ & Create/Control & Approve \\
\hline $\begin{array}{l}\text { Post Qualification } \\
\text { Review }\end{array}$ & $\mathrm{n} / \mathrm{a}$ & Create & Approve \\
\hline \hline
\end{tabular}

\section{References}

1) FNF-PRO-446, Rev. 1., "Testing Requirements", Project Hanford Policy and Procedure System, 1997.

2) HNF-2881, Rev. 0, "Preparation and Testing of Cone Penetrometer Deployable Soil Multi-Sensor and Multi-Sample Soil Sampling Probes: Phase II", Statement of Work to Applied Research Associates, June, 1998. 


\section{DISTRIBUTION SHEET}

\begin{tabular}{|c|c|c|c|c|c|}
\hline \multirow{2}{*}{$\begin{array}{l}\text { To } \\
\text { DISTRIBUTION }\end{array}$} & \multirow{2}{*}{\multicolumn{3}{|c|}{$\begin{array}{l}\text { From } \\
\text { Numatec Hanford Co. }\end{array}$}} & \multicolumn{2}{|c|}{ Page 1 of 1} \\
\hline & & & & \multicolumn{2}{|c|}{ Date $10-19-98$} \\
\hline \multirow{2}{*}{\multicolumn{4}{|c|}{$\begin{array}{l}\text { Project Title/Work Order } \\
\text { Waste Management - HNF-3495, Rev. } 0\end{array}$}} & \multicolumn{2}{|c|}{ EDT No. 617395} \\
\hline & & & & \multicolumn{2}{|c|}{ ECN No. } \\
\hline Name & MSIN & $\begin{array}{c}\text { Text } \\
\text { With } \\
\text { All } \\
\text { Attach }\end{array}$ & $\begin{array}{l}\text { Text } \\
\text { Only }\end{array}$ & $\begin{array}{c}\text { Attach. } \\
/ \\
\text { Appendi } \\
x \\
\text { Only }\end{array}$ & $\begin{array}{l}\text { EDT/ECN } \\
\text { Only }\end{array}$ \\
\hline
\end{tabular}

CENTRAL FILES

PROJECT FILES - HTI

DOE/RL READING ROOM

JW Bloom

WS Cal laway

Mu Horhota

JJ Huston

DF Iwatate

GP Janicek

WJ Kennedy

JG Kristofzski

AF Noonan

RW Root

JM Zimmer
B1-07

R1-41

H2-53

$x$

$x$

$x$

R2-89

S3-90

$\mathrm{B} 1-13$

R2-89

R2-89

S7 -12

S7-03

S7-01

K9-91

R2-53

B1-42
$X$
$X$
$X$
$X$
$X$
$X$
$X$
$X$
$X$
$X$
$X$ 